\section{Brent Spar or Broken Spur?}

SIR - In the Commentary by E. Nisbet and C. M. R. Fowler on 29 June 1995 (ref. 1) and in your Opinion piece in the same issue ${ }^{2}$, the significance of Brent Spar's cargo is measured by the yardstick of the discharge rate of metals by a natural system: the Broken Spur vent field on the Mid-Atlantic Ridge. You say that Broken Spur adds up to $5,000,000$ tonnes of metals annually against which the hundreds of kilograms of metals on Brent Spar is insignificant. Simple comparison of numbers is misleading, because the forms in which metals are added to the environment influences their impact. But, in addition, the figures are wrong.

Nisbet and Fowler quoted their figures from preliminary estimates by R. W. N. and Murton $^{3}$. These were based on metal data obtained in H. E.'s laboratory ${ }^{4}$ and were converted to rates by a procedure which, we now all agree, overestimated metal discharge rates by three to four orders of magnitude.

This is also apparent from other reasoning. The TAG vent field south of Broken Spur is the largest so far discovered and contains about four to five million tonnes of metals. This is similar to the annual rate you quote for Broken Spur, but we know that the TAG deposits have accumulated over 100,000 years 5 . Alternatively, estimates by us and others ${ }^{6}$ place the total annual global metal discharge rate from all vents at roughly 700,000-5,000,000 tonnes a year.

We believe in any case that this comparison is unhelpful. There was no intention to dump the Brent Spar on a vent field; midocean ridge vent fields are sites of special scientific interest. Nisbet and Fowler are careful not to suggest this course, but the linking of Brent Spar with bacteria associated with vents, and the suggestion that midocean ridges may be used as dump sites, could be considered to have this implication.

The total fluxes of all types related to processes within the mid-ocean ridge crest system are poorly known. The waste stored aboard Brent Spar could well act as an energy source for deep-sea bacteria, but may not necessarily benefit species already present; rather, they may be replaced by specialists better adapted to the changed conditions.

To be sure, the mass of the ocean is such

Nisbet, E. \& Fowler, C. M. R. Nature 375, 715 (1995)

Nature 375, 708 (1995)

3. Nesbitt, R. W. \& Murton, B. J. BRIDGE Newslett. 8, 35-37 (1995).

4. James R. H. et al. Geochim. cosmochim. Acta 59, 651-659 (1995).

5. Lalou, C. et al. Earth planet. Sci. Lett. 97, 113-128 (1990).

6. Rudnicki, M. D. \& Elderfield, H. Geochim. cosmochim. Acta 57, 2939-2957 (1993).

7. Brent Spar Abandonment Best Practicable Environmental Option (Shell, 1994).

8. Brent Spar Abandonment Impact Hypothesis (Shell, 1994).

9. Removal and Disposal of the Brent Spar (Aberdeen University and Industrial Services, 1994).

10. Clough, P. \& Davison, J. Sunday Times, 2 July 1995.

11. North Sea Abandonment (S. G. Warburg Research, London, 26 June 1995). that it is likely that the global impact of one oil storage platform would be negligible. Of course, the total global mass of metals in the deep sea is large compared with what is in Brent Spar, but that is not the point. We do not argue for or against dumping in the deep sea, but rather emphasize that comparing figures such as these is oversimplistic. It does not constitute a measure of environmental impact. There is a danger in establishing a precedent in the absence of a proper evaluation, particularly as about a dozen other platforms are due for disposal before the end of the decade.

\section{Harry Elderfield, Adam Schultz \\ Rachael James, Penny Dickson Mervyn Greaves}

Department of Earth Sciences, University of Cambridge,

Cambridge CB2 3EQ, UK

\section{Rachel Mills}

Department of Oceanography,

University of Southampton

\section{Don Cowan}

Department of Biochemistry,

University College London,

London WC1E 6BT, UK

\section{Bob Nesbitt}

Department of Geology,

University of Southampton,

Southampton SO17 1BJ, UK

SIR - Before accusing Greenpeace scientists of "shallowness", perhaps you should have glanced at the documents produced by Shell in support of its original decision to dump the Brent Spar ${ }^{7,8}$.

"Nobody pretends that the ocean floor is a garbage dump of infinite capacity", you state. Yet many of the unjustified assumptions on which Shell based their calculations amount to precisely that suggestion.

Shell reaches the conclusion, for example, that levels of heavy metals would be "negligible", largely by assuming that contaminants will be released slowly over a period of 1,000 years and distributed evenly within a $150-\mathrm{m}$ radius of the source ${ }^{8}$. No data have been made available to support this assertion. The effects of finely dispersed hydrocarbons are described as "insignificant", based on extrapolation from unnamed fouling studies in the North $\mathrm{Sea}^{8}$. These studies are not identified in any way, nor are any data given. The toxicological responses of deep-water organisms are unknown and we are not aware of any toxicity tests that have been carried out on such organisms.

It is difficult to see how it could be claimed that the effect of dumping the Brent Spar would be "minimal or even beneficial", given present knowledge of deepsea ecology and physical processes. It also ignores the political reality that the Brent Spar would have set a precedent for dumping other contaminated structures - each considered on an individual basis, but having a cumulative effect on the environment.

Shell's dumping proposal is in no way justified by Nisbet and Fowler's hypothesis ${ }^{1}$ that a "carefully chosen location on the MidAtlantic Ridge" might be an appropriate disposal site. Shell did not propose disposal at such a site, nor have any detailed studies been made of the effects of Brent Spar's contents at such a site - or indeed, any site. The precise nature of these contents is in any case poorly known and based on very limited measurements ${ }^{9}$. The knowledge that some organisms may benefit from heavy metals tells us nothing about how the ecosystem as a whole will respond to a cocktail of radioactive scale, heavy metals, hydrocarbons and trace quantities of PCBs.

Greenpeace is well aware of the problems of contaminated aquifers and has never proposed dumping in a landfill site as a suitable solution. Engineering firms are queuing up to show that they can dismantle the Brent Spar safely and effectively ${ }^{10}$, as has already been done with hundreds of oil installations in the Gulf of Mexico and nine in the North Sea itself ${ }^{11}$. The pollutants can then be properly dealt with onshore. Treatment of oily wastes and sludge and removal of scale are operations which the oil industry already routinely carries out in land-based facilities.

Finally, we have never ignored the issue of overfishing - the MV Greenpeace is even now out seeking and cutting illegal driftnets. Backed, of course, by sound scientific arguments.

\section{Helen Wallace}

Science Unit, Greenpeace UK, London N1 2PN, UK

\section{Paul Johnston}

Greenpeace Research Laboratory,

University of Exeter, Exeter, UK

SIR - The surrender of the Shell Oil Company to German public opinion over its oil rig is an example of democracy gone wrong and a disaster for future generations. As a result of the misguided lobbying of emotional environmentalists such as Greenpeace, the use of the oceans as a waste depository has been denied to applied scientists competent to take decisions.

Dumping waste in the shallow waters of the North Sea is obviously wrong, but dumping in the Atlantic Ocean several miles down is another matter. Consideration should also be given to dumping vitrified high-level radioactive waste, or even plutonium, sealed in long-life containers in a subduction zone where it would be carried into the mantle in the next 500 years. The missile tubes of nuclear submarines could be fitted with bottom doors to drop such containers to the seabed. The submarines' navigational equipment could locate the drop zone with great accuracy. The Tonga Trench in the Pacific is more than $6 \mathrm{~km}$ deep and hundreds of miles from large human populations.

\section{W. M. Colles}

87 Beaufort Road,

Havant, Hants PO9 3HT, UK 